\title{
Poland and Poles' Miserable Experience Before Operation Barbarossa
}

\begin{abstract}
Yaocheng Zhan
Nanjing Foreign Language School, Nanjing, Jiangsu 210008, China

zhanyaochenghugh@126.com

ABSTRACT

We all know that the Nazis did a lot of barbarous things after the Operation Barbarossa, which brought the Poles and the Jews in Poland untold numbers of disasters. So, we are wondering what the Nazis did before the Operation Barbarossa, was it as cruel as they did after it? With these questions in our mind, this paper focuses on Poland and Pole's miserable experience before Operation Barbarossa. In order to achieve our goal, I looked through a lot of primary and secondary sources during that period to find out what the Nazis did. In the process, I found out that the lightning war is also related to it, so we will research the lightning war at the same time. Finally, the results are obtained through my hard work. In this paper, readers will have a vivid overview of what had happened even before the Operation Barbarossa. This paper will give a brief introduction of the process of the Lightning War and what the Nazis did in occupied Poland such as the Holocaust. The readers will have a clear impression about that period of history and will be sympathetic of Poland and the Poles. After the research, I learned the importance of peace and the urgency of cherishing the peace.
\end{abstract}

Keywords: Poland, Nazis, the Lightning War, holocaust

\section{INTRODUCTION}

As we all know, Poland was the first country to be invaded by Germany in World War Two. The lightning war in September 1939 marked the beginning of World War Two. After occupying Poland one month later, Germany stopped invading the East. Not until June 1941 did Germany start invading the Soviet Union. Therefore, many readers may ask: What was Poland like before Germany invaded the Soviet Union? After all, many historians have blamed the horrors of the Holocaust on the fighting on the Eastern front. But what if the Nazis were already oppressing the Jews before that war began? Most of the historians focus on the study of Poland after the Operation Barbarossa as it gained more characteristic. However, this paper focuses on Poland before Operation Barbarossa although there are really few sources, especially primary sources. The ruined Poland, this paper will show, was suffering a lot under Germany's control before Germany invaded the Soviet Union. This paper analyses the primary sources in detail, which brings the readers a vivid impression of the whole view of that period and what the people who experience it themselves thought about. We can comprehend the cruelty of Nazis and the misery Poles experienced after reading this paper. 


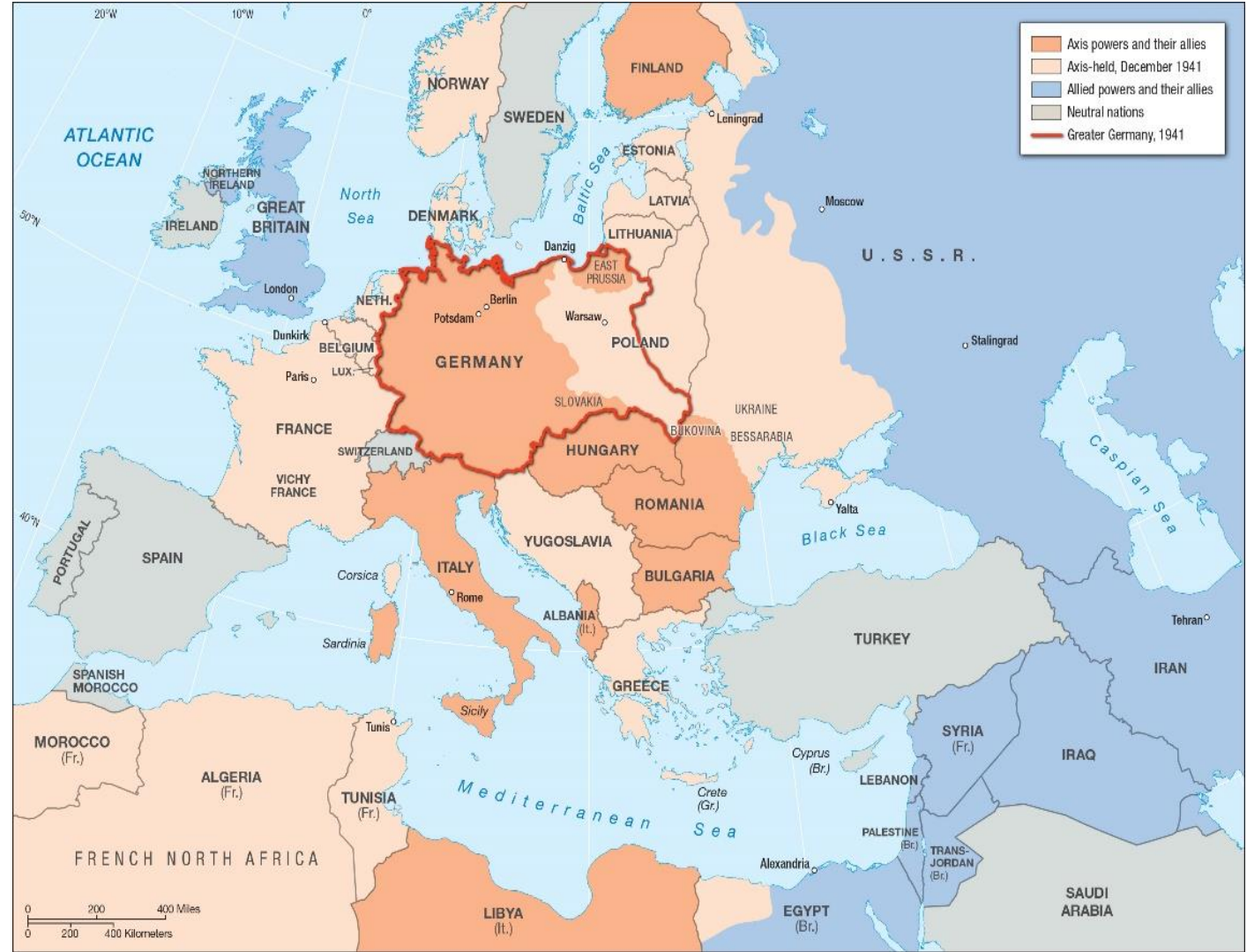

Figure 1 Map of Europe in 1941

\section{BACKGROUND}

First thing first, this paper will introduce the background of that period. On August, 23, 1939, Germany signed the Soviet-German non-aggression treaty with Soviet Union in order not to be attacked on both sides when attacking Poland. In September, 1939, Germany invaded Poland through lightning war and occupied Poland in an astonishing speed. Then, Germany and Soviet Union carved up the territory of Poland. After that, Britain and France declared war with Germany but they didn't let their military attack Germany's territory. Instead, they defensed on their own territory and waiting for Germany's attack. In fact, what Hitler worried most when he forced his military to invade Poland was Britain and France's attack in their back. But due to their own benefits, maybe a few months' peace, they didn't, they chose to watch the war as if it was none of their business. Because of some failures of military actions of Britain, such as the battle in Iceland and Norway, Winston Churchill became the new prime minister of Britain, taking the place of Neville Chamberlain. In May, 1940, Germany began invading France and continued attacking Britain Islands by air until the war ended. [5]

\section{THE LIGHTNING WAR}

\subsection{The process of the Lightning War}

Then, this paper will show an overview of the lightning war towards Poland. Germany's invading Poland marked the beginning of the Second World War. The German invasion began on 1 September 1939 and the Soviets invaded Poland on 17 September. Polish awaited expected support and relief from France and the United Kingdom. Those two countries had pacts with Poland and had declared war on Germany on 3 September, but their aid to Poland was very limited. [1] As a result, Germany finally won the battle and Poland lost. The success of the invasion marked the end of the Second Polish Republic, though Poland never formally surrendered. 


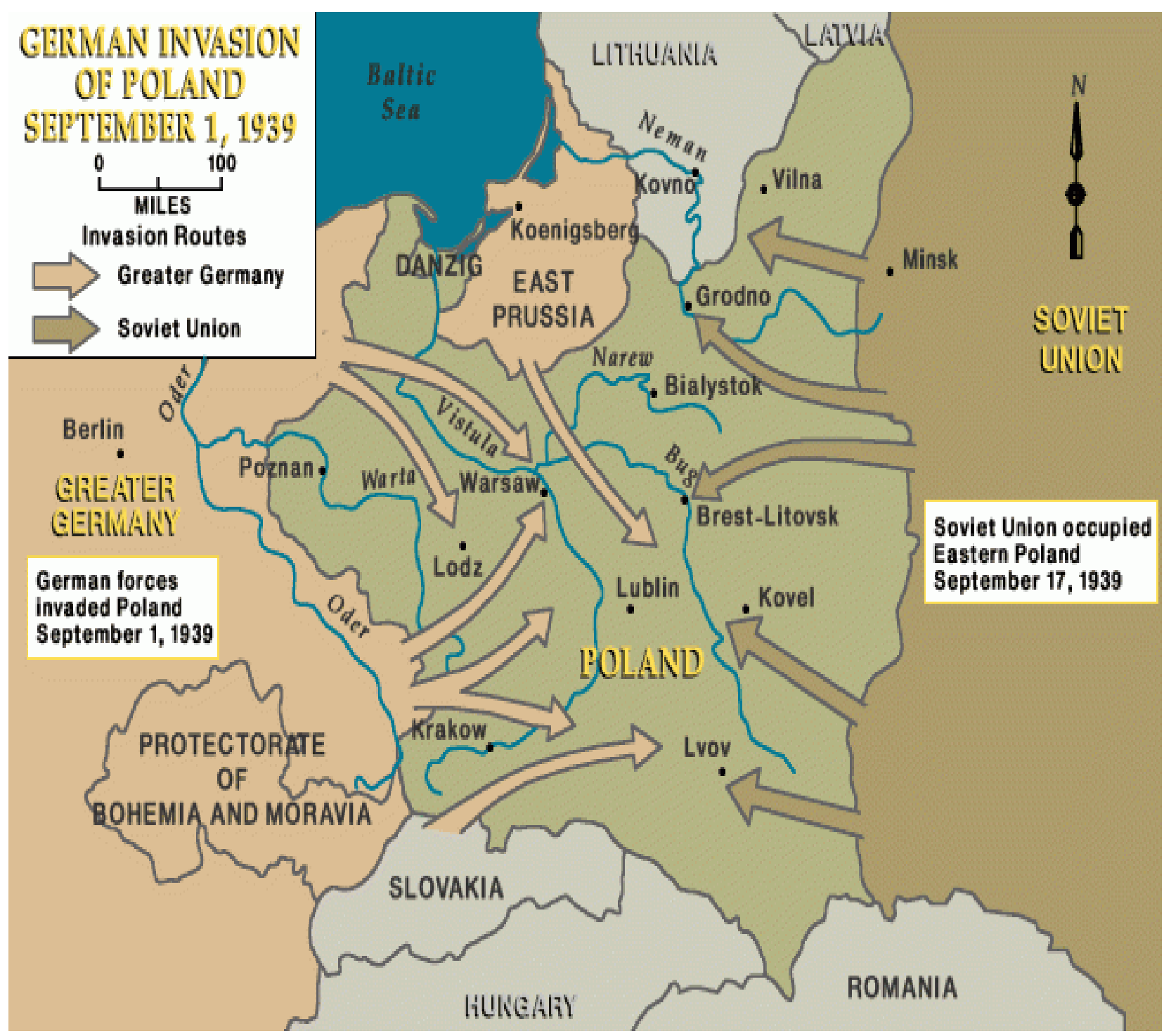

Figure 2 The route of Germany's invasion of Poland

\subsection{The casualties of the Lightning War}

About the casualties of the Invasion of Poland: Nearly 65000 people died and 134000 people injured in the Polish military. About 10576 people died, 30222 people injured and 3400 people disappeared in the German military. In the Soviet Union's military, about 3000 people died, 8000 to 10000 people injured and 5327 people disappeared. [2]

\section{MISERABLE LIVES OF POLES}

\subsection{Sayings from a Polish woman}

Next, this paper will show you what it was like in occupied Poland. Germany was really cruel in Poland even before Operation Barbarossa. Due to the sayings from a woman who witnessed the mistreatment of Jews in Poland, 1940, the main crimes that Nazis committed were that they teased Jews, burned down the two large synagogues and also beat and abused Jews. [3] 


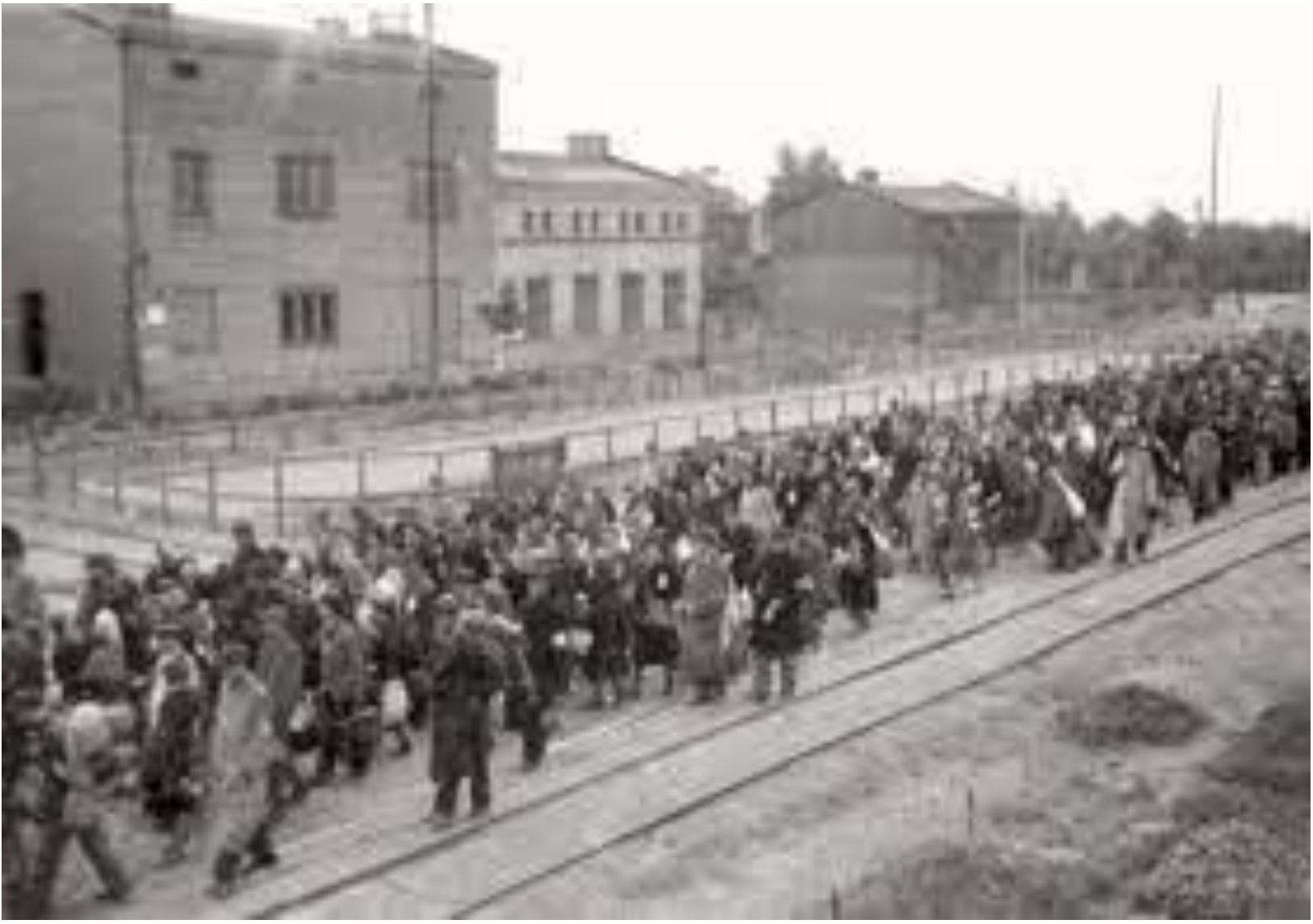

Figure 3 Miserable lives of Poles

She first said that the Nazis forced them into a private house where they were praying, and ordered them to run, or they will be fired and killed. we can see that the Nazis tricked Jews as animals, the Jews needed to follow what they said, or they may lose their life, which shows the cruelty of Nazis.

She then said that the Germans burned down two large synagogues and the fire spread to private houses which cause the Jews lost their possessions. These sayings indicate that the Nazis didn't cherish the others' wealth, they only thought of their own satisfaction, indirectly shows their cruelty.

In addition, she claimed that the Germans caught Jews and forced them to work in the factories, during which they had no food to eat. We can hardly imagine the bad conditions where the Jews worked in, they may suffer from hunger and dirtiness, and starved to death, which revealed that the Nazis didn't care about others, only thought of their own benefits, which is a evidence of their cruelty.

\subsection{A letter from a Polish girl}

Due to a letter written by a Polish girl on $2^{\text {nd }}$, February, 1940, she saw that the Nazis moved Jews in Warsaw from their dwelling places. She also supposed that Nazis are savages without any kind of moral feeling.
This paper suppose most of the readers have the same point of view with her. [4]

At the beginning of her diary, the little Polish girl wrote that the Germans shot the Poles or sent them into prison without any reason at all and filled the prison up quickly. From these few sentences by her, we can know that the Nazis abused the Poles continuously during that period, which showed the Nazis' unreasonable personality.

'If you had lived through the siege, or rather the murder of Warsaw and passed some further months under the rule of the enemy, you would understand they are completely savages without even a vestige of the most commonplace decency or any kind of moral feeling'

These are the main opinion of the Nazis from the writer---a Polish girl, from which we can infer her fierce hatred towards the Nazis, we can imagine her emotion when seeing many compatriots killed by the Nazis without any reasons at all. Except the example of this Polish girl, hundreds of thousands of Poles had the same experience at that period of time, all suffering from the ravage of the Nazis.

All the evidence, such as diaries, letters or saying from residents, all vividly tells as that Nazis was really cruel in Poland even before the Operation Barbarossa. 
Last but not least, I would like to state that many historians share the same opinion with my topic: Nazis were cruel towards Poland and Poles even before the Operation Barbarossa.

\section{CONCLUSION}

To conclude my paper, I would like to say: All the evidence shows that the Poles and Poland the country suffered a lot during World War II, my paper only show their miserable life before the Operation Barbarossa. As we all know, the Holocaust after Hitler teared the SovietGerman non-aggression treaty and invaded Soviet Union was more and more cruel than before the Operation Barbarossa. From which we can learn the cruelty of Nazi Germany and the extremely bad crimes they committed in Poland. This paper analyses the primary sources about the Holocaust in detail and shows a brief introduction of the lightning war, which gives the readers a vivid impression of the whole view of that period and what the people who experience it themselves thought about. I hope readers can understand the cruelty of Nazis and the tragic experience the Poles went through after reading this paper. Therefore, we should remember the bloody history forever and learn to cherish the valuable peace we have today. I hope this paper can also provide as a reference to more and more researchers to study further and replenish what I don't cover in this particular aspect.

\section{REFERENCES}

[1] Kitchen, Martin, A World in Flames: A Short History of the Second World War, Longman, 1990, ISBN 0582-034-086.

[2] Jurga, Tadeusz, Wojna Obronna Polski 1939, Warsaw: Wydawnictwo Ministerstwa Obrony Narodowej, https://web.archive.org/web/20090630054512/http: //ndpbeta.nla.gov.au/ndp/del/article/2513833

[3] "Mistreatment of Jews in Occupied Poland (1940)," Alpha History (https://alphahistory.com/holocaust/mistreatmentjews-in-occupied-poland-1940/)

[4] "Transcript Extracts from a letter written by a young Polish girl (2 February 1940)," National Archives UK (https://www.nationalarchives.gov.uk/education/wo rldwar2/theatres-of-war/westerneurope/investigation/occupation/sources/docs/2/tra nscript.htm)

[5] Senn, Alfred (January 1990). "Perestroika in Lithuanian Historiography: The MolotovRibbentrop Pact". The Russian Review. 49 (1): 4453. doi:10.2307/130082. JSTOR 130082 